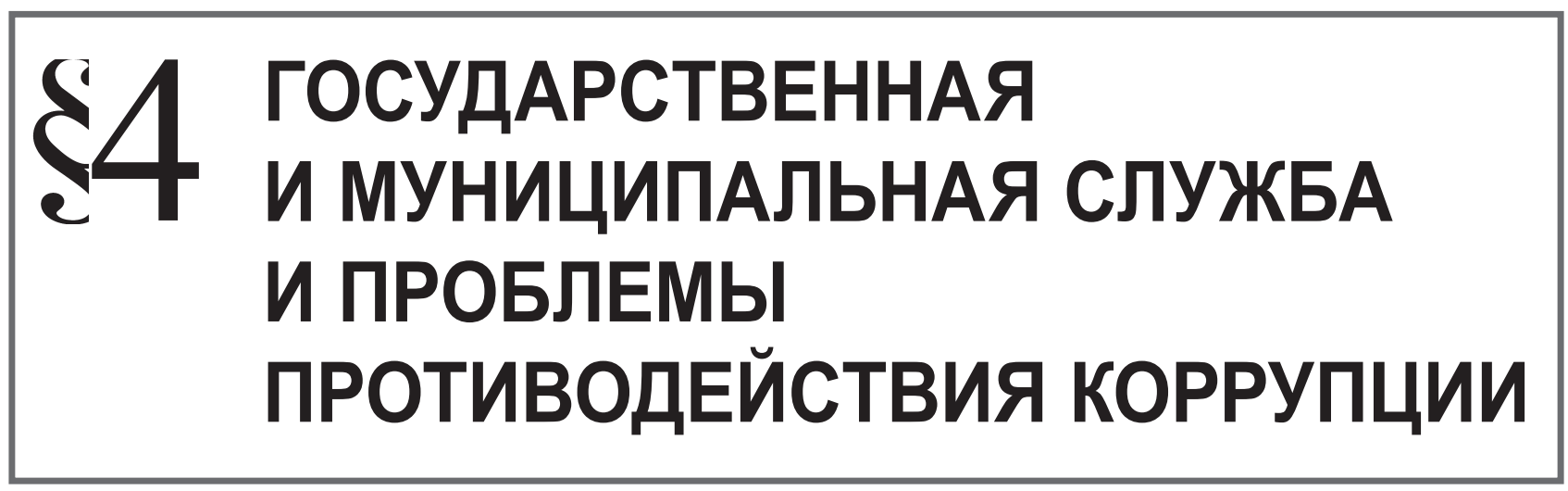

\title{
ПРАВОВЫЕ МЕХАНИЗМЫ ПРОТИВОДЕЙСТВИЯ КОРРУПЦИИ В РОССИЙСКОЙ ФЕДЕРАЦИИ: РЕГИОНАЛЬНЫЙ ОПЫТ (НА ПРИМЕРЕ РЕСПУБЛИКИ ТАТАРСТАН)
}

B се более очевидным становится тот факт, что коррупция как антисоциальное явление оказывает разрушительное воздействие на все правовые институты, в результате чего установленные нормы права заменяются правилами, продиктованными индивидуальными интересами тех, кто способен оказывать влияние на представителей государственной власти и готов за это платить ${ }^{1}$.

Коррупция, по мнению Т.О. Дидыч, явление многогранное, отражающее уровень развития общества, государства и правовой системы. Коррупция возникает, развивается и трансформируется одновременно с государством и правом, с одной стороны как институтов, где она существует, а с другой — как институтов, являющихся средствами противодействия коррупции ${ }^{2}$.

Совершенно очевидно, что противодействие коррупции должно являться одним из самых приоритетных направлений государственной политики (следует отметить, что исходя из содержания многих нормативно-правовых актов, оно таковым и является).

Ни для кого не секрет, что коррупции в большей степени подвержен государственный аппарат, коррупция подразумевает, прежде всего, коррупцию в сфере государственной службы.

\footnotetext{
1 См.: Покровский М.Н. Противодействие коррупции в России: административно-правовые и этические аспекты // Административное и муниципальное право. - 2010. - № 6. - С. 29.

2 См.: Дидыч Т.О. Правотворчество государства и противодействие коррупции в современных условиях // Журнал российского права. - 2012. - № 8. - С. 70.
}

«Чиновник» и «коррупция» - такое отождествление устойчиво бытует в обществе в отношении деятельности государственного аппарата в течение всего обозримого исторического периода ${ }^{3}$.

Допускаемые гражданскими служащими нарушения законодательства снижают эффективность государственного управления, препятствуют проведению скоординированной политики противодействия коррупции, дискредитируют систему органов государственной власти ${ }^{4}$.

Как показывает опыт проводимых государственно-правовых реформ, а также практика правоохранительной деятельности в сфере противодействия коррупции, в системе государственной службы коррупция возникает в тех сферах деятельности органов государственной власти и их должностных лиц, где их статус детально не определён, а также не сформированы административные процедуры предоставления услуг гражданам и юридическим лицам. Различные исследования показывают, что коррупция возникает именно в тех сферах, где государственные служащие реализуют организационные, исполнительно-распорядительные, контрольно-надзорные, юрисдикционные, а также разрешительные полномочия. Вот почему в настоящее время необходимо совершенствовать административ-

\footnotetext{
См.: Булгакова И. Г. Некоторые аспекты профилактики коррупции в органах государственной власти // Журнал российского права. - 2012. - № 8. - С. 75.

См.: Белова С.В., Алексеева Л.Г. Соблюдение законодательства о борьбе с коррупцией // Законность. - 2011. - № 8. - С. 31.
} 
но-правовой режим минимизации коррупционных рисков в профессиональной деятельности государственных служащих ${ }^{5}$.

Противодействие коррупции в системе государственной службы является основой антикоррупционного механизма в целом и служит реализации принципа открытости и публичности в деятельности государственных органов ${ }^{6}$.

Наиболее эффективными средствами противодействия коррупции являются средства правовые. «Действия на основе закона - и по смыслу и по форме должны ограничить это зло» 7 .

Что касается развития так называемой «антикоррупционной законодательной базы», то нельзя не согласиться с тем, что создание полноценного антикоррупционного законодательства непосредственно зависит от имплементации в российскую правовую систему международно-правовых норм, что могло бы обеспечить переход от декларативных норм к действенным правовым способам противодействия коррупции ${ }^{8}$. Кроме того, представляется необходимым широкое применение в России этических международных стандартов служебного поведения госслужащих, изложенных в документах Организации Объединённых Наций и Совета Европы, таких как Международный кодекс поведения государственных должностных лиц 9 , Кодекс поведения должностных лиц по поддержанию правопорядка ${ }^{10}$, Руководящие принципы для эффективного осуществления Кодекса поведения должностных лиц по поддержанию правопорядка ${ }^{11}$ и др.

5 См.: Костенников М.В., Куракин А.В., Колчеманов Д.Н., Марьян А.В. Административно-правовые средства минимизации коррупционных рисков в служебной деятельности государственных служащих зарубежных стран // Административное и муниципальное право. - 2010. - № 5. - С. 6.

6 См.: Овечко В.В. Меры противодействия коррупции в системе государственной службы Российской Федерации // Военно-юридический журнал. - 2011. - № 9. - С. 17.

7 См.: Тихомиров Ю.А., Трикоз Е.Н. Право против коррупции // Журнал российского права. - 2007. - № 5. - С. 40.

8 Овечко В.В. Указ. соч. - С. 17.

9 Международный кодекс поведения государственных должностных лиц (Принят 12 декабря 1996 г. Резолюцией 51/59 на 82-ом пленарном заседании 51-ой сессии Генеральной Ассамблеи ООН) [Электронный ресурс]. - Доступ из справ.-правовой системы «Консультант Плюс».

10 Кодекс поведения должностных лиц по поддержанию правопорядка (Принят 17 декабря 1979 г. Резолюцией 34/169 на 106-ом пленарном заседании Генеральной Ассамблеи ООН) // Международная защита прав и свобод человека. Сборник документов. - М.: Юридическая литература, 1990. - С. 319-325.

11 Руководящие принципы для эффективного осуществления Кодекса поведения должностных лиц по поддержанию
В целом, антикоррупционное законодательство в сфере государственной службы направлено на усиление ограничительного режима для государственных структур, ужесточение ответственности за коррупционные преступления, сделан упор на расширение предупреждения и профилактики коррупционных правонарушений.

Развитие и трансформация антикоррупционной политики в сфере государственной службы по пути ужесточения ограничивающего элемента, строгий учёт и контроль за служебной деятельностью государственных служащих, позволит сделать её наиболее действенным и эффективным способом противодействия «государственной коррупции», предполагающим информационную открытость деятельности должностных лиц государства и позволяющим противодействовать совершению коррупционных преступлений.

Вместе с тем необходимо осознавать, что каждому региону присущи определённая специфика коррупционных рисков, своя структура коррупционных деяний и методы их осуществления. Следовательно, эффективное решение проблем в сфере предупреждения и пресечения различных коррупционных проявлений в деятельности органов государственной власти того или иного субъекта РФ напрямую зависит от разработки и внедрения комплекса мер по противодействию коррупции с учётом требований законодательства, административной реформы, а также региональной специфики ${ }^{12}$.

Следует отметить, что в течение длительного времени региональное антикоррупционное законодательство развивалось со значительным опережением федерального, что позволяет говорить о формировании комплексного законодательного регулирования борьбы с коррупцией.

Исследователи отмечают, что учитывая важность и необходимость противодействия коррупции, а также видя бездействие федеральных органов государственной власти в этой сфере деятельности, отдельные региональные органы государственной власти и их высшие должностные лица стали формировать собственные правовые основы противодействия коррупции, и в том числе собственное региональное антикоррупционное законодательство ${ }^{13}$.

правопорядка (Приняты 24 мая 1989 г. Резолюцией 1989/61 на 15-ом пленарном заседании Экономического и Социального Совета ООН) [Электронный ресурс]. - Доступ из справ.-правовой системы «Консультант Плюс».

12 См.: Короткова О.И. Коррупция и её проявления в системе государственной службы - как одна из наиболее актуальных проблем российской действительности // Государственная власть и местное самоуправление. - 2012. - № 3. - С. 22.

13 См.: Бикмухаметов А.Э., Газимзянов Р.Р., Кабанов П.А. Пробелы в татарстанском антикоррупционном законодатель- 
В числе таких субъектов РФ оказалась и Республика Татарстан, в которой уже с мая 2006 г. действует собственный республиканский Закон «О противодействии коррупции в Республике Татарстан $\rangle^{14}$ (тогда как на федеральном уровне подобный закон был принят лишь в конце 2008 г. $\left.{ }^{15}\right)$.

В Законе Республики Татарстан «О противодействии коррупции в Республике Татарстан» и принятых на его основе нормативных правовых актах были заложены типовые механизмы противодействия коррупции на республиканском уровне, которые в последующем были заимствованы и другими субъектами РФ, принявшими подобные правовые акты ${ }^{16}$. И в целом, региональная программа противодействия коррупции Республики Татарстан является, без преувеличения, одной из передовых.

В самом общем виде следует отметить, что в субъекте сформированы специализированные органы противодействия коррупции; активно реализуются профилактические мероприятия на ведомственном уровне и в муниципальных образованиях; обеспечиваются доступность и открытость деятельности органов государственной власти и местного самоуправления; налажена методическая работа по обеспечению противодействия коррупции; внедряется система добровольного тестирования граждан, претендующих на замещение государственных и муниципальных должностей и т.д.

Анализ нормативно-правовой базы Республики Татарстан позволяет сделать вывод о том, что в рамках борьбы с коррупцией в республике основной упор сделан на расширение арсенала средств противодействия коррупции с использованием в этих целях политических, правовых, экономических, организационных и воспитательных мер. Среди основных мер, можно выделить:

- принятие Стратегии антикоррупционной политики Республики Татарстан ${ }^{17}$. Указанная Стратегия была принята в целях организации эффективной борьбы с коррупцией, устранения порождающих

стве: осмысление регионального опыта // Безопасность бизнеса. - 2008. - № 1. - С. 8.

14 О противодействии коррупции в Республике Татарстан: закон Республики Татарстан от 4 мая 2006 г. № 34-3РТ // Республика Татарстан. - 2006. - 7 мая.

15 О противодействии коррупции: федеральный закон от 25 декабря 2008 г. № 273-Ф3 // СЗ РФ. - 2008. - № 52 (ч. 1). - Ст. 6228.

16 Бикмухаметов А. Э. Указ. соч. - С. 8.

17 О Стратегии антикоррупционной политики Республики Татарстан : указ Президента Республики Татарстан от 8 апреля 2005 г. № УП-127 // Республика Татарстан. - 2005. - 14 апр. её причин и условий, обеспечения законности в деятельности органов государственной власти Республики Татарстан;

- Закон Республики Татарстан от 4 мая 2006 г. № 34ЗРТ «О противодействии коррупции в Республике Татарстан»;

- Постановление Кабинета Министров Республики Татарстан от 18 августа 2011 г. № 687 «Об утверждении Комплексной республиканской антикоррупционной программы на 2012-2014 годы» ${ }^{18}$;

- планирование работы по противодействию коррупции как в целом по республике, так и в министерствах, муниципалитетах (смотри, например, приказ Министерства здравоохранения Республики Татарстан от 11 марта 2012 г. № 313 «О профилактике коррупции и исключения конфликта интересов в учреждениях здравоохранения Республики Татарстан» ${ }^{19}$; постановление Исполнительного комитета муниципального образования город Набережные Челны Республики Татарстан от 15 апреля 2011 г. № 1916 «О мероприятиях по противодействию коррупции в муниципальном образовании город Набережные Челны» ${ }^{20}$;

- создание специального органа при Президенте Республики Татарстан, координирующего и направляющего предупредительную антикоррупционную деятельность (ежегодно министерства и ведомства представляют отчёты о проделанной работе в соответствии с требованиями ст. 14 Закона Республики Татарстан от 04 мая 2006 г. № 34-3РТ «О противодействии коррупции в Республике Татарстан»). Таковым органом в республике является Совет при Президенте Республики Татарстан по противодействию коррупции ${ }^{21}$. Совет при Президенте Республики Татарстан по противодействию коррупции является совещательным органом при Президенте Республики Татарстан по вопросам противодействия коррупции в Республике Татарстан. Совет формируется из числа руководителей

18 Сборник постановлений и распоряжений Кабинета Министров Республики Татарстан и нормативных актов республиканских органов исполнительной власти. $-2001 .-7$ сент.

19 Текст приказа официально опубликован не был [Электронный ресурс]. - Доступ из справ.-правовой системы «Консультант Плюс».

20 Челнинские известия. - 2011. - 20 апр.

21 О Совете при Президенте Республики Татарстан по противодействию коррупции: указ Президента Республики Татарстан от 21 февраля 2011 г. № УП-71 // Сборник постановлений и распоряжений Кабинета Министров Республики Татарстан и нормативных актов республиканских органов исполнительной власти. - 2011. - 6 апр. 
государственных органов Республики Татарстан, структурных подразделений аппаратов Президента Республики Татарстан, Кабинета Министров Республики Татарстан и Государственного Совета Республики Татарстан, территориальных органов федеральных органов исполнительной власти по Республике Татарстан, органов местного самоуправления в Республике Татарстан, а также представителей общественности, в том числе Общественной палаты Республики Татарстан, общественных объединений, средств массовой информации, высших учебных заведений, коммерческих и некоммерческих организаций;

- введение административных регламентов и стандартов предоставления государственных услуг юридическим и физическим лицам, снижающих уровень проявления коррупции (постановление Кабинета Министров Республики Татарстан от 16 июня 2006 г. № 310 «О разработке системы административных регламентов предоставления государственных услуг исполнительными органами государственной власти» 22 ;

- проведение антикоррупционной экспертизы нормативных правовых актов и проектов нормативных правовых актов, в соответствии, как с федеральным, так и региональным законодательством ${ }^{23}$;

- учреждение в министерствах республики, а также в муниципалитетах должности ответственного лица по предупреждению коррупционных правонарушений, а также утверждение министерствами должностных регламентов этих лиц (см., например, приказ Министерства информатизации и связи Республики Татарстан от 28 сентября 2010 г. № П-120 «Об ответственном лице, наделённом функциями по предупреждению коррупционных правонарушений») $)^{24}$;

- осуществление антикоррупционной пропаганды и формирование системы антикоррупционного об-

22 Сборник постановлений и распоряжений Кабинета Министров Республики Татарстан и нормативных актов республиканских органов исполнительной власти. $-2006 .-12$ июля.

23 См., например: Об утверждении Порядка проведения антикоррупционной экспертизы отдельных нормативных правовых актов и проектов нормативных правовых актов и о внесении изменений в отдельные постановления Кабинета Министров Республики Татарстан: постановление Кабинета Министров Республики Татарстан от 24 декабря 2009 г. № 883 // Сборник постановлений и распоряжений Кабинета Министров Республики Татарстан и нормативных актов республиканских органов исполнительной власти. - 2010. - 20 янв.

24 Текст приказа официально опубликован не был [Электронный ресурс]. - Доступ из справ.-правовой системы «Консультант Плюс». разования и воспитания. Так, согласно ст. 12 Закона Республики Татарстан от 4 мая 2006 г. № 34ЗРТ «О противодействии коррупции в Республике Татарстан» антикоррупционное образование является целенаправленным процессом обучения и воспитания в интересах личности, общества и государства, основанным на дополнительных общеобразовательных и профессиональных образовательных программах, реализуемых в образовательных учреждениях среднего общего и высшего профессионального образования для решения задач формирования антикоррупционного мировоззрения, повышения уровня правосознания и правовой культуры, а также подготовки и переподготовки специалистов соответствующей квалификации. Организация антикоррупционного образования возлагается на уполномоченный орган исполнительной власти Республики Татарстан в области образования и науки и осуществляется им во взаимодействии с субъектами антикоррупционной политики на базе образовательных учреждений, находящихся в ведении Республики Татарстан, в соответствии с законодательством РФ и Республики Татарстан.

В данном направлении агентство по массовой коммуникации «Татмедиа» ежегодно проводит журналистский конкурс «СМИ против коррупции». Пропаганда законопослушного образа жизни, предупреждение коррупционных правонарушений в школьной и студенческой среде, как правило, сочетаются с реализацией непосредственных мер противодействия коррупции.

Ещё один из способов борьбы с коррупцией участие в противодействии коррупции институтов гражданского общества (включение представителей общественности в проводимые государственными органами проверки, проведение социологических опросов граждан о распространённости, формах коррупции и наиболее поражённых её сферах). О необходимости взаимодействия органов власти и их должностных лиц с институтами гражданского общества по вопросам противодействия коррупции указывается и в региональном антикоррупционном законодательстве большинства субъектов РФ. При этом под взаимодействием в области противодействия коррупции, в частности в законодательстве Республики Татарстан, подразумевается непосредственное или опосредованное воздействие различных субъектов противодействия коррупции, в том числе органов местного самоуправления и институтов гражданского общества друг на друга и социальную среду для достижения общей цели - снижения уровня коррупции в системе соци- 
ального управления ${ }^{25}$. Формы взаимодействия институтов гражданского общества и органов власти различны. Так, например, в Заинском муниципальном районе в целях осуществления общественного контроля, а также защиты прав и законных интересов граждан в различных сферах жизнедеятельности района из числа депутатов Совета района и г. Заинска создана «Народная инспекция». Практика показала, что народным инспекторам люди доверяют и рассказывают о фактах нарушения законодательства, муниципальных правовых актов ${ }^{26}$.

Действенным инструментом для повышения эффективности реализуемых мер по противодействию коррупции стал Указ Президента Республики Татарстан от 23 марта 2011 г. № УП-148«О мерах по организации и проведению мониторинга эффективности деятельности органов исполнительной власти Республики Татарстан, территориальных органов федеральных органов исполнительной власти по Республике Татарстан, органов местного самоуправления муниципальных районов и городских округов Республики Татарстан по реализации антикоррупционных мер на территории Республики Татарстан» ${ }^{27}$, разработанный совместно Управлением Президента Республики Татарстан по вопросам антикоррупционной политики и Комитетом Республики Татарстан по социально-экономическому мониторингу, а также соответствующее постановление Кабинета Министров Республики Татарстан $^{28}$.

Как уже отмечалось выше, региональное антикоррупционное законодательство развивалось с опере-

25 Кабанов П.А. Некоторые формы взаимодействия институтов гражданского общества с органами местного самоуправления в области противодействия коррупции / П.А. Кабанов // Административное и муниципальное право. - 2012. - № 5. - С. 6.

26 Сводный отчёт о состоянии коррупции и реализации мер антикоррупционной политики в Республике Татарстан в 2011 г. - Казань: Управление Президента Республики Татарстан по вопросам антикоррупционной политики, 2012.

27 Сборник постановлений и распоряжений Кабинета Министров Республики Татарстан и нормативных актов республиканских органов исполнительной власти. - 2011. - № 18. - Ст. 0636.

28 Об организации и проведении мониторинга эффективности деятельности органов исполнительной власти Республики Татарстан, территориальных органов федеральных органов исполнительной власти по Республике Татарстан, органов местного самоуправления муниципальных районов и городских округов Республики Татарстан по реализации антикоррупционных мер на территории Республики Татарстан: постановление Кабинета Министров Республики Татарстан от 10 июня 2011 г. № 463 // Сборник постановлений и распоряжений Кабинета Министров Республики Татарстан и нормативных актов республиканских органов исполнительной власти. - 2011. - № 25. - Ст. 1081. жением федерального. В то же время следствием обозначенной тенденции явились различия в определении понятий, используемых в федеральных нормативных правовых актах о противодействии коррупции и нормативных правовых актах субъектов РФ, что создавало дополнительные сложности в ходе правоприменительной деятельности.

Рассмотрим в качестве иллюстрации антикоррупционные положения федерального закона и закона Республики Татарстан о государственной гражданской службе. Таковыми положениями, в частности, являются положения об ограничениях и запретах налагаемых на государственных гражданских служащих в связи с прохождением государственной службы.

Федеральный закон от 27 июля 2004 г. № 79-Ф3 «О государственной гражданской службе РФ» ${ }^{29}$ в первой своей редакции в ст. 16 предусматривал следующие ограничения, связанные с гражданской службой, а именно:

Гражданин не мог быть принят на гражданскую службу, а гражданский служащий не мог находиться на гражданской службе в случае:

1) признания его недееспособным или ограниченно дееспособным решением суда, вступившим в законную силу;

2) осуждения его к наказанию, исключающему возможность исполнения должностных обязанностей по должности государственной службы (гражданской службы), по приговору суда, вступившему в законную силу, а также в случае наличия не снятой или не погашенной в установленном федеральным законом порядке судимости;

3) отказа от прохождения процедуры оформления допуска к сведениям, составляющим государственную и иную охраняемую федеральным законом тайну, если исполнение должностных обязанностей по должности гражданской службы, на замещение которой претендует гражданин, или по замещаемой гражданским служащим должности гражданской службы связано с использованием таких сведений;

4) наличия заболевания, препятствующего поступлению на гражданскую службу или её прохождению и подтверждённого заключением медицинского учреждения;

5) близкого родства или свойства (родители, супруги, дети, братья, сёстры, а также братья, сёстры, родители и дети супругов) с гражданским служащим, если замещение должности гражданской службы связано с непосредственной подчинённостью или подконтрольностью одного из них другому;

29 СЗ РФ. - 2004. - № 31. - СТ. 3215. 
6) выхода из гражданства РФ или приобретения гражданства другого государства;

7) наличия гражданства другого государства (других государств), если иное не предусмотрено международным договором РФ;

8) представления подложных документов или заведомо ложных сведений при поступлении на гражданскую службу;

9) непредставления установленных настоящим Федеральным законом сведений или представления заведомо ложных сведений о доходах, об имуществе и обязательствах имущественного характера.

Закон Республики Татарстан «О государственной гражданской службе Республики Татарстан» ${ }^{30}$, который, как известно, был принят раньше федерального - 16 января 2003 г., в одной из первых своих редакций предполагал, что государственный служащий не вправе:

1) заниматься другой оплачиваемой деятельностью, кроме преподавательской, научной и иной творческой деятельности;

2) быть депутатом законодательного (представительного) органа государственной власти, органа местного самоуправления;

3) заниматься предпринимательской деятельностью лично или через доверенных лиц;

4) состоять членом органа управления коммерческой организации, если иное не предусмотрено федеральным законом или если в порядке, установленном законом, ему не поручено участвовать в управлении этой организацией;

5) быть поверенным или представителем по делам третьих лиц в государственном органе, в котором он состоит на государственной службе, либо который непосредственно подчинён или подконтролен ему;

6) использовать в неслужебных целях государственное имущество, в том числе средства материально-технического, финансового и информационного обеспечения, и служебную информацию;

7) получать гонорары за публикации и выступления в качестве государственного служащего;

8) получать от физических и юридических лиц вознаграждения (подарки, денежное вознаграждение, ссуды, услуги, оплату развлечений, отдыха, транспортных расходов и иные вознаграждения), связанные с исполнением должностных обязанностей, в том числе и после выхода на пенсию;

9) принимать награды, почётные и специальные звания иностранных государств, международных и

30 О государственной гражданской службе Республики Татарстан: закон Республики Татарстан от 16 января 2003 г. № 3-ЗРТ // Республика Татарстан. - 2003. - 21 янв. иностранных организаций, кроме случаев, предусмотренных федеральным законом;

10) выезжать в служебные командировки за границу за счёт физических и юридических лиц, за исключением служебных командировок, осуществляемых в соответствии с международными договорами РФ или на взаимной основе по договорённости федеральных органов государственной власти и органов государственной власти Республики Татарстан с государственными органами иностранных государств, международными и иностранными организациями;

11) использовать своё служебное положение в интересах политических партий, общественных, в том числе религиозных, объединений для пропаганды отношения к ним. В государственных органах не могут образовываться структуры политических партий, религиозных и других общественных объединений, за исключением профессиональных союзов;

12) принимать участие в забастовках.

Таким образом, по существу, региональный закон предусматривал для государственных гражданских служащих, проходивших государственную службу на территории Республики Татарстан, дополнительные ограничения, либо налагал на них ограничения различные по объёму и содержанию.

Это несоответствие было устранено с принятием Закона Республики Татарстан от 25 октября 2005 г. № $106-3 Р \mathrm{~T}$ «О внесении изменений и дополнений в Закон Республики Татарстан «О государственной гражданской службе Республики Татарстан» ${ }^{31}$.

Кроме того, как уже отмечалось, во многих субъектах РФ, в том числе и в Республике Татарстан, до принятия Федерального закона «О противодействии коррупции» органами законодательной власти были приняты нормативные правовые акты по данному вопросу, что также повлекло за собой трудности в правоприменительной практике.

Однако, следует отметить, что в настоящее время практически всё региональное законодательство, в том числе и в Республике Татарстан, в сфере противодействия коррупции приведено в соответствие с федеральным $^{32}$.

Подводя итог, представляется возможным сделать определённые выводы.

Несомненно, что одним из ключевых средств противодействия коррупции выступает право как средство

31 Республика Татарстан. - 2005. - 29 окт.

32 См., например: О внесении изменений в Закон Республики Татарстан «О противодействии коррупции в Республике Татарстан : закон Республики Татарстан от 19 января 2010 г. № 6-3РТ // Республика Татарстан. - 2010. - 22 янв. 
нормативного правового воздействия, направленного на преодоление и недопущение возникновения и развития коррупционных деяний.

Именно правотворческая деятельность представляет собой основу формирования права, что включает и антикоррупционную составляющую ${ }^{33}$.

Основой антикоррупционных мероприятий должно стать законодательство, учитывающее международные антикоррупционные стандарты и опыт противодействия коррупции в зарубежных государствах.

Как совершенно справедливо отмечает Т.Я. Хабриева, все государственные органы должны быть нацелены на совершенствование системы правоприменения, обеспечение эффективности реализации законов и иных правовых актов, полноценную реализацию полномочий органов и организаций в сферах публичного и частного права, защиту прав и законных интересов граждан. Это требует выработки особой системы показателей и индикаторов, иллюстрирующих эффективность реализации правовых норм $^{34}$.

Эффективность права не равна простой совокупности эффективности отдельных правовых норм и институтов, поскольку право не сводится к их сумме. Для обеспечения эффективности права необходимо постоянное проведение комплекса мероприятий юридического, социально-экономического, воспитательного характера. При реализации сугубо юридических мер необходим отбор тех правовых средств, которые способствуют достижению поставленной цели. Это и научное обеспечение правотворчества, и новые процедуры реализации законов и т.п. ${ }^{35}$

Исходя из анализа антикоррупционного законодательства Республики Татарстан, а также складывающейся в республике ситуации в сфере противодействия коррупции, следует отметить, что антикоррупционная политика республики должна развиваться по следующим направлениям:

- организация работы по приведению республиканского законодательства и муниципальных нормативных правовых актов в соответствие с федеральным законодательством в связи с необходимостью совершенствования государственного управления в области противодействия коррупции;

- информирование населения о реальной коррупционной ситуации в республике и мерах, принимаемых органами публичной власти по реализации антикоррупционной политики;

- предупреждение коррупционных правонарушений и сокращение условий для возникновения коррупции;

- повышение эффективности взаимодействия органов власти с гражданским обществом, государственная поддержка деятельности общественных организаций по противодействию коррупции;

- последовательное применение имеющихся правовых, образовательных и воспитательных мер, направленных на противодействие коррупции.

\section{Библиографический список:}

1. Белова С.В. Соблюдение законодательства о борьбе с коррупцией / С.В. Белова, Л.Г. Алексеева // Законность. 2011. - № 8. - C. 30-33.

2. Бикмухаметов А.Э. Пробелы в татарстанском антикоррупционном законодательстве: осмысление регионального опыта / А.Э. Бикмухаметов, Р.Р. Газимзянов, П.А. Кабанов // Безопасность бизнеса. — 2008. — № 1. — C. 7-10.

3. Булгакова И.Г. Некоторые аспекты профилактики коррупции в органах государственной власти / И.Г. Булгакова // Журнал российского права. — 2012. — № 8. - С. 75-80.

4. Дидыч Т.О. Правотворчество государства и противодействие коррупции в современных условиях / Т.О. Дидыч // Журнал российского права. — 2012. - № 8. - С. 69-74.

5. Кабанов П.А. Некоторые формы взаимодействия институтов гражданского общества с органами местного самоуправления в области противодействия коррупции / П.А. Кабанов // Административное и муниципальное право. — 2012. — № 5. - С. 5-8.

6. Короткова О.И. Коррупция и её проявления в системе государственной службы - как одна из наиболее актуальных проблем российской действительности / О.И. Короткова // Государственная власть и местное самоуправление. - 2012. - № 3. - С. 22-25.

33 Дидыч Т.О. Указ. соч. - С. 70.

34 Хабриева Т.Я. Коррупция и право: доктринальные подходы к постановке проблемы // Журнал российского права. 2012. - № 6. - C. 10 .
35 Хабриева Т.Я. Экономико-правовой анализ: методологический подход // Журнал российского права. - 2010. - № 12. - С. 21. 
7. Костенников М.В. Административно-правовые средства минимизации коррупционных рисков в служебной деятельности государственных служащих зарубежных стран / М.В. Костенников, А.В. Куракин, Д.Н. Колчеманов, А.В. Марьян // Административное и муниципальное право. - 2010. - № 5. - С. 5-20.

8. Овечко В.В. Меры противодействия коррупции в системе государственной службы Российской Федерации / В.В. Овечко // Военно-юридический журнал. — 2011. — № 9. — С. 17-18.

9. Покровский М.Н. Противодействие коррупции в России: административно-правовые и этические аспекты / М.Н. Покровский // Административное и муниципальное право. — 2010. — № 6. — С. 28-30.

10. Тихомиров Ю.А. Право против коррупции / Ю.А. Тихомиров, Е.Н. Трикоз // Журнал российского права. 2007. - № 5. - С. 39-52.

11. Хабриева Т.Я. Коррупция и право: доктринальные подходы к постановке проблемы / Т.Я. Хабриева // Журнал российского права. — 2012. - № 6. - С. 5-17.

12. Хабриева Т.Я. Экономико-правовой анализ: методологический подход / Т.Я. Хабриева // Журнал российского права. — 2010. — № 12. - С. 5-26.

\section{References (transliteration):}

1. Belova S.V. Soblyudenie zakonodatel'stva o bor'be s korruptsiey / S.V. Belova, L.G. Alekseeva // Zakonnost'. 2011. - № 8 .

2. Bikmukhametov A.E. Probely v tatarstanskom antikorruptsionnom zakonodatel'stve: osmyslenie regional'nogo opyta / A.E. Bikmukhametov, R.R. Gazimzyanov, P.A. Kabanov // Bezopasnost’ biznesa. — 2008. — № 1.

3. Bulgakova I.G. Nekotorye aspekty profilaktiki korruptsii v organakh gosudarstvennoy vlasti / I.G. Bulgakova // Zhurnal rossiyskogo prava. — 2012. - № 8 .

4. Didych T.O. Pravotvorchestvo gosudarstva i protivodeystvie korruptsii v sovremennykh usloviyakh / T.O. Didych // Zhurnal rossiyskogo prava. — 2012. - № 8 .

5. Kabanov P.A. Nekotorye formy vzaimodeystviya institutov grazhdanskogo obshchestva s organami mestnogo samoupravleniya v oblasti protivodeystviya korruptsii / P.A. Kabanov // Administrativnoe i munitsipal'noe pravo. 2012. 一 № 5 .

6. Korotkova O.I. Korruptsiya i ee proyavleniya v sisteme gosudarstvennoy sluzhby — kak odna iz naibolee aktual'nykh problem rossiyskoy deystvitel'nosti / O.I. Korotkova // Gosudarstvennaya vlast' i mestnoe samoupravlenie. 2012. - № 3 .

7. Kostennikov M.V. Administrativno-pravovye sredstva minimizatsii korruptsionnykh riskov $\mathrm{v}$ sluzhebnoy deyatel'nosti gosudarstvennykh sluzhashchikh zarubezhnykh stran / M.V. Kostennikov, A.V. Kurakin, D.N. Kolchemanov, A.V. Mar’yan // Administrativnoe i munitsipal'noe pravo. — 2010. — № 5.

8. Ovechko V.V. Mery protivodeystviya korruptsii v sisteme gosudarstvennoy sluzhby Rossiyskoy Federatsii / V.V. Ovechko // Voenno-yuridicheskiy zhurnal. — 2011. — № 9.

9. Pokrovskiy M.N. Protivodeystvie korruptsii v Rossii: administrativno-pravovye i eticheskie aspekty / M.N. Pokrovskiy // Administrativnoe i munitsipal'noe pravo. — 2010. — № 6 .

10. Tikhomirov Yu.A. Pravo protiv korruptsii / Yu.A. Tikhomirov, E.N. Trikoz // Zhurnal rossiyskogo prava. 2007. 一 № 5 .

11. Khabrieva T.Ya. Korruptsiya i pravo: doktrinal'nye podkhody k postanovke problemy / T.Ya. Khabrieva // Zhurnal rossiyskogo prava. — 2012. — № 6 .

12. Khabrieva T.Ya. Ekonomiko-pravovoy analiz: metodologicheskiy podkhod / T.Ya. Khabrieva // Zhurnal rossiyskogo prava. - 2010. — № 12 . 